\title{
BOEKBESPREKING
}

\section{DE INFORMATIEVERSCHAFFING IN EEN MIDDELGROOT BEDRIJF IN NEDERLAND}

Rapport van Werkgroep III van het Nederlands Instituut voor Beleidsinformatie (NIBIN, Parkstraat 18, Den Haag). December 1971, 36 blz. A 4 .

\section{door Prof. A. B. Frielink}

Dit rapport bevat een zgn. Case-study (in het rapport aangeduid als, ,werkmodel'). Bij de $\mathrm{Ne}$ derlandse Hardmetaal Fabrieken N.V. te Arnhem heeft de werkgroep onderzocht op welke wijzen aan de informatiebehoeften wordt voldaan.

De beperkingen die de gekozen methode oplevert zijn in de lnleiding duidelijk vermeld: Er kunnen geen uitspraken met algemene geldigheid worden gedestilleerd uit een onderzoek van één bedrijf; de studie heeft geen weten schappelijke pretentie.

Het rapport verschaft gecomprimeerd, duidelijke achtergrond-informatie omtrent het bedrijf: omvang (ca. 230 personeelsleden), produktieproces, in- en verkoopmarkten, organisatie-structuur, functie- en taakomschrijvingen.

Zowel uit de tekst, als uit het veelomvattende schema van de informatie-kringloop blijkt dat in dit bedrijf de coördinatie van (en voor een zeer groot deel ook de verwerking van gegevens voor) de informatievoorziening bij de sector administratic ligt. Men zou wensen dat deze situatie zich bij veel meer bedrijven van vergelijkbare omvang voordeed, en vooral ook dat de opleiding van administrateurs in het bijzonder er op gericht zou zijn om mensen op te leiden die een zodanige centrale plaats in het informatievoorzieningsproces kunnen innemen. Comptabele kennis is daarbij wel onmisbaar, doch niet voldoende.
Node mist men in het rapport een aanwijzing hoe en door wie nu eigenlijk de informatiebehoefte wordt bepaald. Op blz. 10 staat wel dat het mede tot de taak van de sector administratie behoort de informatievoorziening voortdurend op de informatiebehoefte afgestemd te houden, maar of het initiatief tot aanpassing voornamelijk uitgaat van de administrateur, dan wel van de betrokken leidinggevende functionarissen of hun directe chefs (de directie) wordt niet duidelijk. Het meest waarschijnlijke is dat hier sprake is van een wisselwerking; doch dat veronderstelt een bekwaamheid en een bereidheid van alle betrokkenen zich in de problemen van de anderen te verdiepen, die normaliter niet zonder bewuste sturing vanuit de top worden bereikt.

Met een tegenspraak in het rapport kan ik niet goed uit de voeten. Op blz. 6 wordt gemeld or dat beleidsvorming en beleidsformulering bij de NHF een aangelegenheid is van een team;

- dat de beleidsuitvoering daar een aangelegenheid is van een persoon (directeur of leidinggevende medewerker;"

Op blz. 13 wordt echter bericht:

„De ,grote staf' (bestaande uit de 5 hoofden van dienst) houdt zich niet alleen bezig met het vaststellen van het beleid, maar ook met de uitvoering daarvan,....".

Het onderscheid is van belang voor de informatievoorziening. Uit het schema op blz. 11 , waar alle informatiestromen ten behoeve van de bijsturing getekend zijn als lopende via de ,grote staf', krijgt men de indruk dat de uitspraak op blz. 6 maar ten dele waar is.

Kennisneming van het rapport wordt van harte aanbevolen aan directeuren en verdere leidinggevenden in middelgrote en kleinere ondernemingen en vooral aan administrateurs die hun functie boven die van een boekhouder willen laten uitgroeien. 


\section{Dr. J. van Rees}

\section{EXPORT-MARKETING}

H. E. Stenfert Kroese N.V., Leiden 1971. 144 pagina's. Prijs, ingenaaid $f$ 22,- .

\section{door Dr. H. W. de Jong}

Dit boekje, uitgegeven in de serie export en welvaart, die onder redactie van $A$. Heertje bij Stenfert Kroese verschijnt, beoogt een systematische benadering van de exportmarkt, haar onderzoek en haar aanpak te geven. Daarbij acht de schrijver, blijkens zijn woord vooraf, exportmarketing ,meer een kunst dan een wetenschap". Het komt mij voor dat het geen van beide is, maar een „kunde" welke voornamelijk steunt op ervaring opgedaan in het exportwerk, aangevuld met een grote dosis gezond verstand en achtergrondinformatie. Wanneer dit alles in gesystematiseerde vorm in een boekje wordt verzameld kan men spreken van export-marketing. Van Rees brengt dit onder in vier gedeelten: Wat is marketing en waar houdt de exportmarketing zich speciaal mee bezig? Hoe komt de oriëntatic op de buitenlandse markt tot stand en hoe gaat men te werk? Wat omvat het exportmarktonderzoek: wat zijn de mogelijkheden en moeilijkheden? En tenslotte: hoe gebruikt men de marketing-planning ten dienste van de export?

De auteur heeft zijn doelstelling: een systematische behandeling te geven van de vraagstukken dic bij de export-marketing een rol spelen, zeker waargemaakt. Allerlei aspecten passeren de revue en verkrijgen hun plaats, zodat de presentatic overzichtelijk is geworden, en, gemeten aan de omvang van het boekje, een grote mate van volledigheid wordt bereikt. Daardoor leent het werkje zich er goed toe om aan betrekkelijke beginners in handen te worden gegeven, zodat zij zich op de hoogte kunnen stellen van de mogelijkheden en mocilijkheden van het vak.

Een twectal kritische opmerkingen mogen echter niet achterwege blijven. Ten cerste: het boekje had o.i. belangrijk aan waarde kunnen winnen door ecn aantal, gevallen" van succesvolle en mislukte export-marketing campagnes uitvoeriger te bchandelen. Nu wordt weliswaar hier en daar in de tekst (o.a. p. 48/49), alsmede in een bijlage gewezen op enkele geslaagde "marketing-cases" maar de beschrijuing is te summier om van nut te zijn. Wat verder ook de nadelen mogen zijn van een ,case-methode”, zij helpt in ieder geval de vorming van het vermogen tot a) diagnoseren van problemen, b) het analyseren van bepaalde bedrijfssituaties en c) het zoeken en vergelijken van alternatieve oplossingen. Dit is zowel voor de praktijkman als voor de student nuttig.

Een tweede punt van kritiek sluit nauw hierbij aan. Iedere auteur van een boek over export-marketing ziet zich geconfronteerd met het probleem dat ook Van Rees signaleert: t.w. het terrein van actie wordt gevormd door een zeer grote verscheidenheid van markten waarvoor geen algemene recepten van bewerking kunnen worden gegeven. Hoe dan toch over "export-marketing" te schrijven valt in onderscheid van de algemene marketing is een dilem ma waruit Van Rees zich vooral redt door zoals reeds gezegd - systematisch de factoren die in de export-marketing een rol spelen te be spreken. Het bezwaar is dan evenwel dat er te weinig diepgang in de behandelde onderwerpen is en met name dat het eigene van de exportmarketing niet voldoende naar voren komt. Om maar enkele dingen te noemen: de produktcyclus wordt genoemd, maar de betekenis ervan en de toepassing op het exportbedrijf worden niet belicht. Over de distributie worden enkele opmerkingen gemaakt (p. 47 e.v.), o.a. dat een eenvoudiger structuur van de distributie gepaard gaat met een geringere econom ische ontwikkeling, maar dieper inzicht wordt niet geboden, terwijl cr toch een uitgebreide literatuur over bestaat, te beginnen met McNair's Distribution Costs - An International Analysis (1941).

Ongetwijfeld had Export-Marketing zowel door de case-bchandeling, als door deze verdieping een omvangrijker boek geworden. O.i. was dat geen bezwaar geweest; ten slotte bestaat er nauwclijks geschiktc Nederlandse literatuur over dit belangrijke onderwerp. Misschien mogen we daarom de hoop uitspreken dat de auteur - die het terrein goed kent - of de redactie in haar serie nog eens op dit onderwerp wil (laten) terugkomen. 


\section{BOEKBESPREKING}

Prof. Dr. J. F. Haccoû

\section{TERMIJNHANDEL, TERMIJNMAR KTEN EN SPECULATIE (GOEDEREN)}

H. E. Stenfert Kroese N.V., Leiden, 1971, 180 bladzijden, $f$ 25,-

\section{door Prof, Dr. J. A. Geertman}

Dit boek is een aanvulling van het proefschrift van de auteur van 1940, waarvan de handelsuitgave verscheen in 1947. Het is een doorwrocht geschrift, noodzakelijk geworden omdat op dit gebied zoveel veranderd is. In de hoofdlijn van het boek is sinds 1940 niet veel gewijzigd. De schrijver zegt in het Voorwoord: „De bedoeling van deze publicatie is niet om $\mathrm{mijn}$ vroegere boek te vervangen, doch om voor de termijnhandel en zijn vraagstukken door een beknopte behandeling begrip te wekken bij een ruimere kring van belangstellenden; wil men een diepere analyse van het vraagstuk bestuderen, dan moge naar mijn reeds genoemde uitvoerige studie worden verwezen. In de thans gegeven beschrijving zal aandacht worden besteed aan de na 1945 verschenen literatuur".

Het belang van de termijnhandel voor de prijsvorming blijkt vooral uit een staatje op blz. 27. Zo werd in een bepaald jaar voor tarwe op de termijnmarkt het vijfvoud, voor sojabonen het zesvoud van de oogst omgezet.

Natuurlijk zijn in 31 jaar de gedachten van de auteur uitgerijpt. Het nieuwe boek bevat dan ook wat minder feiten en is iets abstrakter dan het proefschrift. De goederen, die ter sprake komen, zijn: granen, oliën en vetten, voedingsmiddelen, vezels, metalen, overige goederen. Van de laatste categorie was er in het proefschrift reeds een uitgebreide opsomming. Sindsdien zijn er bij gekomen: appelen, uien, sinaasappelsap, vismeel, levend vee, delen van geslacht vee, kalkoenen, braadkuikens. Ook is voor een aantal artikelen sinds 1940 de termijnmarkt verdwenen en $z i j n$ plaatselijke termijnmarkten opgeheven. Zo bijv. deed de Amerikaanse landbouwpolitiek met haar minimumprijzen de termijnmarkt in katoen in New Orleans verdwijnen. Haccoû is zuiver bedrijfseconomisch. Ergo wordt deze macro-economische oorzaak niet vermeld.

Meer dan in het proefschrift is in het nieuwe boek het accent gelegd op de betekenis van de termijnmarkt voor de prijsvorming, zo zelfs, dat de mogelijkheid van levering als een onvol- komenheid wordt gezien (blz. 172), hoewel zij essentieel is om de band te handhaven met de naturamarkt. Reeds Limperg wees in zijn colleges op het feit, dat een ,zwarte piet" de prijsvorming op de termijnmarkt kan verstoren.

Een verdere storing is de speculatie door het publiek. Dit verschijnsel doet zich vooral in de Verenigde Staten voor, waar zg. „bucketshops” bestaan, dat zijn bedrijven, welke het publiek gelegenheid geven op het prijsverloop te gokken zonder dat zij transacties ter beurze doen (blz. 53).

De termijnhandel is vooral van betekenis omdat meestal tot 12 maanden vooruit mag worden verhandeld. Voor een vrij groot aantal goederen is dit zelfs 18 maanden (blz. 67). De termijnhandel reguleert de prijzen op vrij lange termijn.

Het bestuur van de termijnmarkt wenst geen sterke fluctuaties in de prijzen. Soms zijn maximale verschillen met de vorige slotnotering vastgesteld, soms wordt de handel tijdelijk onderbroken bij te grote fluctuaties (blz. 68/9).

De auteur accentueert het grote belang van de beroepsspeculatie voor een goede prijsvorming (blz. 78), zo ook het natuurlijke verband tussen de prijzen van de opeenvolgende termijnen en de storende werking van een corner; alsmede de ongewenste invloed van gelegenheidsspeculanten op de prijsvorming. Voor een goede prijsvorming is het voorts van belang, dat het aantal van de gevallen, waarin het op de termijnmarkt tot levering komt, gering is. Het normale percentage ligt tussen 1 en $2 \%$ van het aantal contracten. Dit is voldoende om de paralleliteit in de prijzen van natura- en termijnmarkten te handhaven. Opgemerkt moet worden, dat voor incourante maanden deze percentages aanzienlijk hoger liggen. De natuurlijke verschillen tussen de prijzen van de opeenvolgende termijnen worden gevormd door opslagkosten en renteverlies: in feite zijn deze verschillen prijzen voor het bewaren (biz. 110).

Bedrijfseconomisch is de betekenis van de termijnmarkt vooral gelegen in de mogelijkheid tot hedging. Sinds 1940 zijn er nieuwe technieken ontstaan (blz. 122 e.v.). In verband met hedging spreekt Haccoû van, ,reële" termijnaffaires.

Het boek houdt zich niet bezig met termijnhandel in valuta's en effecten. Maar ook de goederentermijnmarkt kan gebruikt worden ter dekking van valutarisico. Bijzonder actueel en interessant is het voorbeeld van blz. 132: ,. . het dekken van het valutarisico van een daling 
van het f-sterling door een importeur van Britse goederen (andere dan wol) met een voorraad, door twee contracten in wol te Antwerpen: een koop van wolcontracten in sterling tot het totaal van de sterling-vervangingswaarde van de voorraad - waardoor men sterling schuldig wordt - tegen een verkoop van evenveel wolcontracten in Belgische franken, waardoor men zijn wolpositie sluit".

Het begrip "hedging" is sinds 1940 ruimer geworden. Een voorbeeld (blz. 134) is het volgende: in de fabricage van electrotechnische artikelen en in de non-ferro-metaalindustrie koopt men liever op de termijnmarkt dan dat men het systeem gebruikt van voorkoop van grondstoffen. De belangrijkste reden is, dat annulering op de termijnmarkt veel goedkoper uitkomt dan op de naturamarkt (blz. 135).

Hedging kan een middel zijn om een betere bedrijfsbezetting te verkrijgen. Een voorbeeld vormen de graansilo's in de Verenigde Staten. Als de silo's leeg raken, worden granen op de naturamarkt gekocht en opgeslagen. Dit zal voordelig zijn als de differentieel gecalculeerde opslagkosten lager zijn dan de prijsverschillen tussen de vroegere en de latere termijnen. De terminologie van Haccoû is iets anders: genoegen nemen met een vergoeding van minder dan de totale kosten van de opslag, genoegen nemen met een kleiner report in de termijnprijs.

Gebruik van de termijnmarkt kan de financiering goedkoper maken. Is er een tegentransactie op de termijnmarkt, dan wordt in de Verenigde Staten bankcrediet gegeven tot $90 \%$ van de waarde van de goederen, zulks in plaats van de gebruikelijke $65 \%$. Er zijn meer financieringsvoordelen, waarvan een opsomming wordt gegeven op blz, 141.

Het begrip arbitrage van Haccoû heeft een grotere omvang dan gebruikelijk is. Arbitrage is niet beperkt tot geografische verschillen, maar vindt ook plaats tussen de verschillende termijnen op dezelfde markt. Er is ook arbitrage tussen kwaliteiten en herkomsten. Ten slotte be staat er arbitrage tussen goederen en geld. Wat deze laatste vorm betreft, citeer ik (blz. 156): „Een verhoǵing van de rentestand zal ertoe leiden, dat men zijn geld uit de investering in goederen terugtrekt en naar de geldmarkt overbrengt. Dit veroorzaakt verkoop van goederen op de naturamarkt met een druk op de prijzen, alsmede indekking van lopende termijnverkopen en ook, als nieuwe hedges worden afgesloten, een groter wordend report".

De geografische arbitrage op de naturamarkt is niet eenvoudig. De oorzaak hicrvan is tweeërlei. Ten eerste is er het tijdsverschil tussen ont- vangst op de ene en levering op de andere markt. De tweede oorzaak doet zich voor, als de relatief goedkope markt de achterliggende markt is. In dat geval zal terugzending plaats vinden naar de voorliggende markt.

De termijnmarkten kennen deze moeilijkheden niet. De arbitrage tussen termijnmarkten omvat vier transacties. De voor arbitrage in rekening gebrachte commissie is de helft van de normale. Bovendien wordt een lager depôt geëist.

Haccoû heeft goed werk gedaan door in dit boek de stof te brengen op het niveau van de huidige tijd, het begrippenapparaat te verhelderen, nieuwe voorbeelden te geven, verouderde opvattingen te corrigeren. Het boek bevat geen register, maar dat is in dit geval ook niet zo belangrijk. Het literatuuroverzicht omvat 116 titels, waarvan 18 Nederlands en 1 Duits. De hele rest is Engels.

In het Voorwoord zegt de auteur, dat de behandeling in de leerboeken soms van een zeer bescheiden kennis met betrekking tot het onderwerp getuigt. Ik weet uit ervaring, dat het uiterst moeilijk is deze stof in enkele woorden naar voren te brengen. Vergelijkt men bijv. Haccoû met de Amerikaanse Samuelson, achtste druk, blz. 401/2, dan blijkt in Samuelson de specialistische behandeling wel wat veel geofferd te zijn an de didactick. Natuurlijk is hetgeen in Samuelson staat niet onjuist. Voor het vormen van goede begrippen, die de specialist op dit gebied tot tevredenheid kunnen stemmen, is $2 \frac{1}{2}$ kolom, zoals in Samuelson, niet genoeg. Ik vraag mij af of in de Verenigde Staten een samenvattend werk bestaat, zoals dat van Haccoû. Zo ja, dan kan er best een tweede of een derde bij. De termijnhandel is zulk een belangrijke institutie in de prijsvorming in de vrije maatschappij, dat verdere studie steeds zal leiden tot een dieper inzicht in het maatschappelijk gebeuren. Samuelson beperkt zich tot het prijsrisico. Het accent ligt bij hem op hedging. Het is bij deze specialistische stof zeer moeilijk een korte samenvatting te geven. Uiteraard heeft de auteur van een leerboek - bij Samuelson in oorsprong bestemd voor technische studenten voor wie de economie een bijvak is , vergeleken met Haccoû, wiens publicaties zich uitstreken van 1940 tot 1971, een bescheiden kennis. De verhouding van de lecrboekschrijver tot de specialist is als die tussen manager en specialist. $Z_{i j}$ moeten clkaar aanvullen.

Het zal zelden voorkomen, dat een proefschrift ruim een generatic later in het licht van gewijzigde omstandigheden cen aanvulling krijgt 
of opnieuw geschreven wordt. Het nieuwe boek is zo uniek en belangrijk, dat het verspreiding verdient buiten het Nederlandse taalgebied. Vooral in de Verenigde Staten zal er belangstelling voor bestaan en met name in Illinois.

Sinds 1964 ben ik van de bedrijfseconomie overgeschakeld naar de macro-economie. In dit verband zal de lezer begrijpen, dat ik gaarne een antwoord gezien had op vragen als de volgende: Waarom zijn er geen termijnmarkten in communistische landen? Waarom werden vanaf 1933 in Duitsland de termijnmarkten a fgeschaft en kwamen zij na 1945 terug? Welke betekenis hebben termijnmarkten voor ontwikkelingslanden? Wat is de toekomst van de termijnmarkt mede in verband met de groei van de, affluent society"? Welke invloed heeft de Amerikaanse landbouwpolitiek op de termijnmarkten? Hoe staat het met de internationale grondstoffenovereenkomsten? Is er verband tussen de landbouwpolitiek van de E.E.G. en termijnmarkten? De man van de wetenschap heeft het recht van zulke vragen te abstraheren, de practicus niet.

In een tweede druk zou ik gaarne een hoofdstuk zien over de betekenis van de termijnmarkten voor het Nederlandse bedrijfsleven. Haccoû behandelt vooral de Nederlandse termijnhandel in aardappelen. Maar er is meer. Zo bijv. heeft Lips in Drunen normaliter een negatieve economische voorraad. Het prijsrisico voor koper en zink wordt gedekt op de termijnmarkt van de Londense metaalbeurs. Zie J. A. geertman en A. H. Geertman, Economisch-technische verschijn- selen, deel 1, vierde druk, 1971, blz. 104. De negatieve economische voorraad is het gevolg van orders voor scheepsschroeven.

In het boek van Haccoû wordt uiteraard niet gesproken over termijnhandel in effecten en die in valuta. Het voorbeeld van blz, 132 betreft dekking van valutarisico, maar met behulp van termijnhandel in goederen.

De auteur heeft zich volgens het Voorwoord tot taak gesteld niet te vervallen in diepgaande theoretische analyses. Toch zou iets meer theorie nuttig kunnen zijn. Alfred Marshall heeft gezegd: „The economist must be greedy of facts; but facts by themselves teach nothing" en Walter Eucken: „Die Theorie steht noch am Anfang, noch am Ende, sondern in der Mitte des Erkenntnisprozesses". Met deze opmerkingen bedoel ik het zoeken van nog iets meer contact met de prijsvorming als geheel.

Het boek is zorgvuldig gecorrigeerd. Echter is een enkele storende drukfout blijven staan. Op blz. 63 regel 6 staat 3000 kilo. Dit moet 30.000 kilo zijn.

In verband met mijn suggestie van een Engelstalige versie wil ik nog wijzen op een aantal termen en begrippen, die een eigen inhoud hebben, zodat de vertaling moeilijkheden kan opleveren, omdat men daarvoor in Amerika geen zuiver equivalent heeft. Ik bedoel termen en begrippen als: bedrijfskolom, oerproducent, voortstuwen, inkoopmarkt, afzetmarkt, vervangingswaarde, vermogen. Het zal zaak zijn misvattingen bij Amerikaanse studenten te voorkomen. 


\section{BOEKBESPREKING}

Drie rapporten uitgegeven door het Nederlands Studiecentrum voor Informatica. ${ }^{1}$ )

\section{door Dr. G. Bresser}

1 Functies in de automatische informatie verzorging (1971 Samsom, prijs f 3,- excl. BTW).

Rapport van de Werkgroep Functiebepaling van de Commissie Overleg inzake Personeelsproblemen. (COPP).

In de inventarisatie van aktiviteiten op het gebied van de automatische informatieverwerking ligt een eerste verdienste van dit rapport. De samenstellers geven aan dat zij ten behoeve van hun rapportage hebben gekozen voor een benadering vanuit de functie en niet vanuit de organisatievorm. De functie, als doel van een recks van aktiviteiten, wordt echter niet duidelijk onderscheiden van de met een persoon verbonden taak. Ondanks de aanvankelijke bedoelingen ontkomt men dan ook niet aan een belangrijk element in de organisatorische vormgeving; het vaststellen van de takinhoud. Binnen de functie programmering wordt bijvoorbeeld aandacht besteed aan de taken van de programmatuurdeskundige, de wetenschappelijk programmeur en de applicatieprogrammeur.

De betekenis van rapporten als deze is tot op zekere hoogte beperkt omdat in de groepering van de aktiviteiten en de daarmee verbonden benoeming van de taken betrekkelijk willekeurig te werk kan worden gegaan. Deze groepering van aktiviteiten is uiteindelijk bepalend voor de waarde van die taken in een organisatie. Het is met de beschikbare inventarisatie van taakelementen echter goed mogelijk een vergelijking te maken tussen de taken zoals die in verschillende organisaties voorkomen.

Het valt op dat de gehanteerde benamingen van de taken niet volledig zijn geënt op het spraakgebruik. De systeemanalist komt bijvoorbeeld niet voor terwijl een weinig gangbare benaming als informatie-analist voor een omvangrijke analitische taak zijn intrede doet. Indien de nicuwe termen inderdaad ingang vinden kan tegen deze wijzigingen overigens weinig bezwar worden gemaakt. Na de informatieanalist wordt achtercenvolgens aandacht besteed aan de taak van de systeemontwerper, de drie reeds genoemde taken binnen de program-

1) Opgenomen in de losbladige uitgave ,Het beheer van computers". Uitgave Samsom, Alphen aan de $\mathrm{R}$ ijn. meringsfunctie, de operateur van geavanceerde computersystemen en de console-operateur.

Belangwekkend is voorts de indicatie die van de opleiding voor elke taak wordt gegeven. Zowel het algemeen vormend onderwijs, het beroepsonderwijs, de vakopleiding als de opleiding op het gebied van de informatica worden besproken.

Tenslotte worden de doorstroom mogelijkheden tussen de verschillende taken in kaart gebracht.

Helaas blijven de functie van de werkvoorbereiding en de darmee verbonden taken buiten beschouwing. Juist nu vaak kan worden waargenomen dat de taken van de operateur en de werkvoorbereider uitdrukkelijk worden gescheiden is het aantrekkelijk de functies waar de betrokken taken deel van uitmaken duidelijker te markeren.

Overigens voorziet een dergelijk rapport duidelijk in een behoefte. Geregelde herziening verdient aanbeveling.

2 Het Hoofd Informatie Verwerking (1971 Samsom, prijs $f$, - excl. BTW)

Een enquête naar de taak en de functie van degenen die in bedrijven en instellingen belast zijn met de leiding van automatiseringsactiviteiten. H. W. Dijkstra en E. Kruithof.

In de eerste twee hoofdstukken van hun rapport hebben de auteurs het empirische mate riaal verwerkt waarmee zij de organisatorische plaats van het HIV en de inhoud van zijn taak willen beschrijven. Vergelijkend organisatieonderzoek is echter altijd erg moeilijk. Dat zullen niet alleen de auteurs van deze brochure hebben ondervonden. In de bespreking van het eerste rapport kwamen soortgelijke problemen naar voren. Het beoordelen van het materiaal is extra moeilijk wanneer de auteurs - zoals hier bij voorbaat menen het juiste niveau van het $\mathrm{HIV}$ in de organisatiestructuur te kennen.

De organisatorische plaats wordt beoordeeld aan de hand van gegevens met betrekking tot de rang en het rapporteren van het HIV. In beide gevallen worden termen als direkteur, onderdirekteur, hoofd administratie en chef boekhouding gehanteerd. Welke begrippen op die manier worden gedekr blijft onduidelijk. Ook de betekenis van de warschuwende woorden die de auteurs verbinden aan het feit dat $z i j$ hebben geconstateerd dat in 7 gevallen (van de 56) het HIV bij nieuwe automatiseringsprojec 
ten niet op „direktie-niveau" rapporteert is zeer beperkt (blz. 7). Voor dergelijke uitspraken geeft hun brochure te weinig achtergrondinformatie.

In aansluiting op de organisatorische plaats van het HIV, die met niet of slechts ten dele gedefinieerde begrippen wordt gemarkeerd, komt ook de inhoud van zijn taak maar matig uit de verf. Drie elementen worden genoemd:

- Leiding dagelijkse gang van zaken in het computer centrum.

Advisering ten aanzien van nieuwe automatiseringsprojecten.

- Uitgebreide rapportage over automatische informatieverwerking.

Organisatorisch is de vorm van het computercentrum (besproken in het vijfde hoofdstuk), de betekenis van het advies en de aard van de rapportage zo summier beschreven dat vergelijking met andere - de lezer bekende - situaties niet goed uitvoerbaar is.

Bij de bespreking van de feitelijke en de gewenste opleiding van het HIV blijkt dat slechts in 14 van de 54 gevallen het HIV een academische of NIVRA-opleiding heeft genoten. Daarnaast komen MO of SPD opleidingen voor (21) en heeft een grote groep maximaal een MBA opleiding (16). Vooral op de management $k$ waliteiten van het HIV wordt in veel bedrijven de nadruk gelegd. Zesenzestig procent van de ondervraagden heeft overigens zelf een voorkeur voor een speciale studierichting automatische informatieverwerking. Zeer specifieke opleidingsbehoeften, vanuit de taak die een HIV vervult, komen echter niet naar voren.

Het onderzoek leverde overigens nog enkele wetenswaardigheden op die niet direkt met het onderwerp verbonden zijn.

- In $68 \%$ van de onderzochte bedrijven werden bij het toepasbaarheidsonderzoek externe adviseurs ingeschakeld. Het waren vooral de grootste bédrijven die geen gebruik maakten van de diensten van buitenstaanders.

De verhouding tussen het aantal systeemanalisten en het aantal programmeurs bij de onderzochte organisaties was gemiddeld $1: 2$. Uitschieters naar boven waren echter de industrie, 62:100 en de overheid 67:100, naar beneden de bank-, crediet- en verzekeringsbedrijven 39:100.

Zoals vele managers, meent ook het HIV dat hij te veel tijd aan leidinggeven moet besteden en te weinig tijd voor studie en eigen onderzoek beschikbaar hecft. Wellicht valt een dergelijk verschijnsel terug te voeren tot een ver. langen naar vroegere - lees gemakkelijker taken.
Het is op zichzelf nuttig dat onderzoek wordt gedaan naar de taak en functie van een HIV. Als zodanig verdient deze brochure alle lof en kan als een goede aanzet worden gezien.

Er blijkt echter duidelijk een nog groter behoefte te bestaan: Een éénduidig begrippenapparaat waarmee organisaties, taken en funkties kunnen worden beschreven en daardoor ook vergeleken. In feite een empirisch gefundeerde organisatietheorie.

3 Datatransmissie. (1971 Samsom, prijs $f$ 9,75 excl. BTW)

Rapport van de Commissie Datatransmissie

Dit rapport is verschenen op een moment dat er sprake is van een voortdurend toenemende belangstelling voor datatransmissie als onderdeel van een automatisch informatieverwerkend systeem. Het kan in deze ontwikkeling een belangrijke rol vervullen.

De brochure is gesplitst in twee delen. In de eerste plaats wordt andacht besteed aan belangrijke technische begrippen, apparatuur, programmatuur en enkele facetten die bij het ontwerpen van datatransmissiesystemen een rol spelen. In de tweede plaats worden de functies van datatransmissie besproken, waarbij per functie aan een achttal aspecten aandacht wordt gegeven.

In het eerste deel ligt de nadruk, met name in het hoofdstuk Transmissie, op de technische bijzonderheden die bekend moeten zijn om met vrucht over datatransmissiesystemen te kunnen oordelen. Ondanks de beperkte ruimte die voor een dergelijke uiteenzetting in het kader van een brochure beschikbaar kan worden gesteld geeft dit hoofdstuk een zeer duidelijk overzicht van de veelheid van, soms nauw verweven, technische begrippen. Daarnaast wordt in algemene zin enige aandacht besteed aan apparatuur en programmatuur. Helaas worden in de paragraaf gewijd aan de programmatuur, voor zover ik heb kunnen nagaan, niet precies dezelfde begrippen gebruikt als in de brochure - Functies in de automatische informatieverzorging .. Met name het begrip systeemprogrammatuur wordt nu regelmatig gebruikt. De inhoud van dit begrip is echter ten opzichte van de begrippen programmatuur en applicatieprogramma's (gebruikersprogramma's) niet duidelijk begrensd.

Tenslotte worden in dit eerste deel enkele functionele aspecten van het systeemontwerp geintroduceerd, bij toepassing van datatrans- 
missie ten behoeve van automatische informatieverwerking.

In het tweede deel worden achtereenvolgens datacollectie, datadistributie, mens-machine dialoog en datatransmissie tussen computers, als functies van datatransmissie aan de orde gesteld. Het ligt voor de hand dat de analyses van datacollectie en datadistributie het meest essentiële inzicht in het betrokken probleemgebied verschaffen. De beide andere functies kunnen tot op grote hoogte als afgeleiden worden gezien. Binnen iedere functie wordt niet alleen aandacht besteed aan: het ontstaan, de vastlegging, verwerking, het transport en de beveiliging van informatie, ook systeem, apparatuur en programmatuur aspecten worden behandeld. Het was voor de commissie uiteraard moeilijk in algemene zin iets over de functies te zeggen. De onderlinge verhoudingen van de aspecten binnen één functie zijn sterk afhankelijk van de toepassing in een gegeven organisatie. Het tweede deel maakt dan ook noodzakelijkerwijze een enigszins fragmentarische indruk. Steeds heeft men echter getracht een reeks factoren te bespreken die van belang zijn voor het ontwerpen van informatiesystemen die van datatransmissie gebruik maken. In het kader van deze brochure mag daarbij geen volledigheid worden verwacht. Voor de realisatie van een concrete toepassing wordt echter een goede handleiding geboden. Gegeven een specifiek probleem is het mogelijk snel en vooral systematisch thuis te raken op een gebied vol voetangels en klemmen.

Samenvattend menen wij te mogen stellen dat:

- Het rapport voorziet in een duidelijke behoefte.

- De aanpak, vooral in de totale opzet, systematisch is en daardoor naar eigen behoefte kan worden aangepast en uitgebreid.

- Het geheel zich goed laat lezen.

- De noodzakelijke definities grotendeels duidelijk zijn vermeld.

- Terecht nadruk is gelegd op de organisatorische facetten. 


\section{J. M. Middag en G. van Muiden}

\section{NIEUW HUURRECHT BEDRIJFSRUIMTEN}

Serie Recht en Praktijk, 6b, Kluwer-Deventer, 1971, 126 blz., f 16,50

\section{door Prof. Mr. Drs. J. Th. Degenkamp}

"Nieuw huurrecht bedrijfsruimten" is een op de praktijk gerichte verhandeling over de op 1 mei 1971 in werking getreden nieuwe bepalingen m.b.t. huur en verhuur van bedrijfsruimten en onteigening van verhuurde bedrijfsruimten. Deze co-produktie is - naar de auteurs in het voorwoord vermelden - in zo korte tijd tot stand gekomen, dat zelfs de tijd ontbrak elkaars aandecl te bestuderen en te critiseren. Dat het register ook aan de snelheid ten offer is gevallen, is jammer. Vooral voor ,praktijk”-mensen niet-juristen zal het niet gemakkelijk zijn iets „na te slaan". De nieuwe bepalingen vormen namelijk een van de minder doorzichtige gedeelten van ons verbintenissenrecht; in een andere context (De Praktijkgids, juni/juli 1971) heb ik de term ,rimboe" gebruikt.

De auteurs komen uit makelaars- resp. kleine-ondernemersorganisatie kringen; belangheb benden aan meestal verschillende kanten van de tafel. Dat de inwerkingtreding van de nicuwe regels gepaard zou gaan met een lawine van opzeggingen, huurverhogingen, protest-demonstraties etc., is door weinigen vermoed. De omstandigheden waren kennelijk minder ,, min of meer normaal" dan door de wetgever werd verondersteld. De kantonrechters is een zware taak extra toebedeeld; een nieuwe groep ,personae miserabiles" verdrong zich voor de gebouwen van de kantongerechten (zic A. J. B. Verheijen, „De Kantonrechter", 1971, pag. 18)

Een korte samenvatting van de inhoud van het boek:

Hoofdstuk [I, III en IV geven de kernpunten van het nieuwe recht, de wetsgeschiedenis en wat de auteurs noemen de ,rechtsgrond" van de nieuwe regeling, maar wat ik liever de sociale en bedrijfseconomische achtergronden zou wil len noemen.

Hoofdstuk V en VI vormen de romp van het boek. Hoofdstuk V geeft de nieuwe B.W.-bepalingen, hoofdstuk VI de nieuwe bepalingen m.b.t. onteigening en gedwongen ontruiming i.v.m. de uitvoering van werken in het algemeen belang.
Hoofdstuk VII en VIII bevatten het procesrecht en het overgangsrecht.

Als bijlage is de tekst van de wet toegevoegd.

Zoals bekend behoort de rechtspraak naast de wetgeving tot de bronnen van ons geldend recht. Naarmate een wettelijke regeling meer vage begrippen bevat (i.c. ,vergelijkbare bedrijfsruimte"; ,bedrijfsvoering van de huurder is niet zoals een goed huurder betaamt"; ,de verhuurder (heeft) geen overwegend belang"; de huurder wordt door het verlies van het gehuurde ,ernstig getroffen" etc.), wordt de ,,speelruimte" van de rechterlijke beslissing groter en kan de onzekerheid omtrent te verwachten beslissingen toenemen. Deze onzekerheid wordt weer kleiner als de eerste golf uitspraken is ver werkt. Vooral de praktijk zal m.i. behoefte hebben aan een tweede druk waarin deze uitspra ken plus de verwijzingen naar literatuur niet ontbreken.

Tenslotte een paar opmerkingen over de inhoud, die niet de pretentie hebben een volledige critiek te leveren.

Op p. 13 wordt gesteld dat de nicuwe wettelijke regeling het ,juiste midden" vormt tussen de cigenaar van het pand, de verhuurder, en de eigenaar van de onderneming, de huurder. Aangezien het Nederlandse recht de onderneming niet als ,zaak' erkent (de schrijvers stellen dat het niet erkennen het begrip ,onderneming" betreft, maar dit is vermoedelijk een verschrijving), zijn schrijuers van mening dat het ,op het cerste gezicht wat moeilijk te begrijpen is dat de eigenaar van het pand in zijn verhouding tot de ondernemer/huurder beperkingen worden opgelegd" (pag. 14). Begrippen als ,het juiste midden" en ,evenwichtig samenspel van vraag en aanbod op de markt van bedrijfspanden" ( $p$. 15) suggcreren het bestaan van een harmonischer werkelijkheid dan mij gerechtvaardigd lijkt; het onderscheid tussen analyse en waardering van de nieuwe rechtsregels en de situatie op de markt is door de schrijvers niet overal even goed in het oog gehouden. Voorts ontgat mij waarom de bescherming van de huurder (cen betrekkelijke zekerheid t.a.v. de huurtermijn voor 10 jaar) t.o.v. de cigenar-verhuurder ,op het ecrste gezicht moeilijk te begrijpen is". Het atatal contracten warbij het positicve recht eigenaren beperkt in hun bevoegdheden ten opzichte van degenen aan wic zij cen van hun recht afgeleid recht hebben verleend (z.g. beperkte rechten) is immers niet gering; of heeft 
het beeld dat de eigenaar ,du haut de sa grandeur" beperkte rechten afsplitst de schrijvers parten gespeeld?

Op pag. 69 wordt m.i. wel erg gemakkelijk heengelopen over de mogelijkheid om de dwingend-rechtelijke regels te omzeilen. Art. 1629 lid 3 B.W. bepaalt dat overeenkomsten tot beëindiging van een huurovereenkomst die zijn gesloten nadat de huurovereenkomst is aangegaan, niet behoeven te worden goedgekeurd door de kantonrechter. Bij de behandeling van het ontwerp-wet is gewezen op de mogelijkheid dat een aspirant-huurder bij het sluiten van de huurovereenkomst een niet gedateerde verklaring te tekenen krijgt waarin hij verklaart de overeenkomst "vrijwillig" te beëindigen; het invullen van de datum kan dan later naar behoefte door de verhuurder geschieden. De opmerking van schrijvers: „Het heeft weinig zin partijen te beschermen als zij daaraan geen van beiden behoefte hebben. Daarom kan er weinig bezwaar bestaan tegen een vroegtijdige beëindiging van de huurovereenkomst in onderling overleg", doet daarom nog al mager aan.

Als laatste een voor de praktijk belangrijk punt dat zowel in de literatuur als in de rechtspraak al een rol heeft gespeeld. Art. 1631a B.W. bepaalt dat een verzoek tor verlenging van de huurovereenkomst door de rechter alleen mag worden toegewezen als de verhuurder "geen overwegend belang bij het beëindigen van de huur heeft" en de huurder ",door het verlies van het gehuurde ernstig zou worden getroffen" (cumulatieve voorwaarden). Naar het inzicht van de schrijvers (p. 74) behoort tot de belangen van de verhuurder de mogelijkheid van verkoop „vrij van huur". Het verschil tussen de verkoopprijzen verhuurd-onverhuurd levert h.i. een „overwegend belang" op. In T.V.V.S. december 1971, p. 401 e.v. is hiertegen stelling genomen door P. de Prez. Volgens De Prez heeft niet de oude maar de nieuwe eigenaar bij verkoop belang bij het eindigen van de huur. Een merkwaardige redenering omdat bij vervreemding de marktwaarde voor de eigenaar toch wel relevant lijkt te zijn. Is alleen het verhuurd zijn oorzaak van de lagere waarden, dan kan de verhuurder art. 1631 a lid 2 sub. 5 juncto lid 7 B.W. in het geweer roepen; de prijs wordt dan aangepast aan die van vergelijkbare panden; stemt de huurder daar niet mee in, dan wordt de overeenkomst niet verlengd. De "hardheid" van de hierna te behandelen beslissing wordt dan ook niet veroorzaakt door art. 1631a B.W. maar door de artt. VIII en IX van de nieuwe wet die overgangsrecht bevatten.

Op grond van deze bepalingen geld $\mathrm{o}$.a. dat bestaande lopende overeenkomsten die voór 1 mei 1972 waren opgezegd als datum van het einde van de overeenkomst 30 juni 1972 mochten aangeven. Deze bestaande huurovereenkomsten vallen onder het "na-10-jaar-régime" dat de huurder minder bescherming verleent.

De kantonrechter te Amsterdam besliste op 3 september 1971 dat ,onder het hier bedoelde belang (van 1631 a B.W.) moet worden verstaan het belang van de verhuurder om over het tot dan toe verhuurde object vrij te kunnen beschikken". De huurder die zich bereid verklaarde een huurprijs te betalen ,die in juiste relatie staat tot de waarde (van het pand)" verloor de zaak o.a. omdat de rest van het complex voor het grootste deel vrij van huur was en het naar het inzicht van de kantonrechter een feit van algemene bekendheid, althans hem uit eigen wetenschap bekend was dat parterre-winkelruimte op het Damrak "bijzonder gewild" is. In hoeverre ook andere voorspellingen van de schrijvers juist zijn (ze kunnen een self-fulfilling prophecy karakter hebben!) zal een hopelijk spoedig verschijnende aangevulde tweede druk ons leren. 